\title{
Simulasi dan Analisis Kinerja Prediktor Smith pada Kontrol Proses yang Disertai Tundaan Waktu
}

\author{
Neilcy Tjahja Mooniarsih \\ Program Studi Teknik Elektro Jurusan Teknik Elektro \\ Fakultas Teknik, Universitas Tanjungpura \\ e-mail : neilcyte@gmail.com
}

\begin{abstract}
Tundaan waktu sering diabaikan pada tahap perancangan tanpa meninjau efek yang akan ditimbulkan pada saat hasil rancangan di implementasikan. tundaan waktu dapat berdampak pada menurunnya kinerja kontrol menjadi menurun atau bahkan gagal. Sistem kontrol prediktif merupakan salah satu solusi yang mungkin, untuk mengatasi dampak dari adanya tundaan waktu di dalam sistem kontrol proses. Perubahan perilaku sistem hanya dapat dilakukan melalui penambahan suatu sub sistem, yaitu kontroler. Kontroler PID merupakan jenis kontroler yang paling populer dan banyak diterapkan di dunia industri. Kontroler PID dalam banyak kasus telah terbukti memberikan unjuk kerja yang relatif memuaskan, baik digunakan sebagai sistem regulator maupun sebagai sistem servo. Namun, untuk sistem kontrol proses yang disertai dengan tundaan waktu, PID belum memberikan kinerja yang memuaskan. Tundaan waktu adalah salah satu masalah yang paling serius dalam meningkatkan kinerja kontrol. Penelitian menyajikan simulasi, dan analisis pendekatan prediktor Smith untuk mengkompensasi tundaan waktu agar dapat meningkatkan kinerja kontroler PID konvensional. Jika model tersedia, maka efek dari aksi kontrol yang terjadi pada keluaran proses ke depannya dapat diprediksi tanpa menunggu sepanjang tundaan waktu. Model matematika yang digunakan untuk menghasilkan variabel proses yang disturbance-free memiliki dua elemen yang terhubung secara seri. Elemen pertama mewakili semua perilaku proses yang tidak disebabkan oleh tundaan waktu. Dan elemen kedua hanya berupa tundaan waktu. Strategi Smith menghadirkan suatu estimasi tentang seperti apa variabel proses tanpa adanya disturbance dan tundaan waktu ke dalam jalur umpan balik.
\end{abstract}

Keywords-Proses, Tundaan waktu, PID, Prediksi, Prediktor Smith

\section{Pendahuluan}

Keberadaan kontroler dalam sebuah sistem kontrol mempunyai kontribusi yang besar terhadap perilaku sistem. Pada prinsipnya hal itu disebabkan oleh tidak dapat diubahnya komponen penyusun sistem tersebut. Artinya, karakteristik plant harus diterima sebagaimana adanya, sehingga perubahan perilaku sistem hanya dapat dilakukan melalui penambahan suatu sub sistem, yaitu kontroler. Salah satu tugas komponen kontroler adalah mereduksi sinyal galat, yaitu perbedaan antara sinyal referensi dan sinyal aktual. Hal ini sesuai dengan tujuan sistem kontrol yaitu mendapatkan sinyal sinyal yang diinginkan, yang nilainya sama dengan sinyal referensi. Semakin cepat reaksi sistem mengikuti sinyal aktual dan semakin kecil sinyal galat yang terjadi, semakin baiklah kinerja sistem kontrol yang diterapkan. Apabila perbedaan antara nilai sinyal referensi dengan nilai sinyal keluaran relatif besar, maka kontroler yang baik seharusnya mampu mengamati perbedaan ini untuk segera menghasilkan sinyal keluaran untuk mempengaruhi plant. Dengan demikian sistem secara cepat mengubah sinyal keluaran plant sampai diperoleh selisih antara sinyal referensi dengan besaran yang diatur sekecil mungkin. Untuk mendapatkan aksi kontrol yang baik diperlukan langkah-langkah sebagai berikut: Memahami cara kerja sistem, mencari model sistem dinamik dalam persamaan differensial, mendapatkan fungsi alih sistem dengan Transformasi Laplace; Memberikan aksi pengontrolan dengan menentukan konstanta-konstanta kontroler yang sesuai; Menggabungkan fungsi alih yang sudah didapatkan dengan jenis aksi pengontrolan, menguji sistem dengan sinyal masukan fungsi langkah, fungsi undak dan impuls ke dalam fungsi alih yang baru. Melakukan Transformasi Laplace balik untuk mendapatkan fungsi dalam kawasan waktu, menggambar tanggapan sistem dalam ranah waktu.Tundaan waktu sangat sering terjadi pada saat penerapan sistem kontrol proses dalam dunia nyata, yang disebabkan oleh satu atau lebih hal-hal berikut: Pengukuran variabel sistem, properti fisis dari peralatan yang digunakan di dalam sistem, dan transmisi sinyal (transport delay). Pada saat perancangan dan analisis, delay sering diabaikan tanpa meninjau efek yang mungkin akan ditimbulkan pada saat hasil rancangan diimplementasikan. Aksi kontrol yang cepat sekalipun tidak mampu mengoreksi dampak dari delay tersebut sehingga kinerja kontrol menjadi menurun atau malah gagal. Sistem kontrol prediktif merupakan salah satu solusi yang mungkin, untuk mengatasi dampak dari adanya tundaan waktu di dalam sistem kontrol proses.

Kontroler PID ini merupakan jenis kontroler yang paling populer digunakan yang banyak diterapkan didunia industri. Luasnya penggunaaan kontroler PID 
pada dasarnya dilatar belakangi oleh beberapa hal diantaranya kesederhanaan struktur kontrol. Selain hanya ada 3 parameter utama yang perlu diatur, pengaruh perubahan setiap parameter PID terhadap dinamika pengontrolan secara intuitif mudah dipahami oleh operator. Kontrol PID memiliki sejarah yang panjang yang telah digunakan jauh sebelum era digital berkembang. Kontrol PID dalam banyak kasus telah terbukti menghasilkan unjuk kerja yang relatif memuaskan, baik digunakan sebagai sistem regulator (sistem kontrol dengan set point konstan dan beban cemderung berubah-ubah) maupun sebagai sistem servo (sistem kontrol dengan set point yang berubah dan beban cenderung konstan).

Paper ini menyajikan simulasi dan analisis pendekatan prediktor Smith untuk mengkompensasi tundaan waktu untuk memperbaiki kinerja kontroler PID konvensional. Model matematika yang digunakan untuk menghasilkan variabel proses disturbance-free memiliki dua elemen yang dihubungkan secara seri. Pertama, mewakili semua perilaku proses yang tidak disebabkan oleh tundaan waktu. Kedua, hanya tundaan waktu. Unsur time-delay-free umumnya diimplementasikan sebagai turunan biasa atau persamaan difference yang mencakup estimasi dari semua penguatan proses dan konstanta waktu proses. Sinyal yang masuk ke dalamnya menjadi tertunda saat keluar, sedangkan jika pada kondisi sebaliknya tidak berubah. Strategi Smith menghadirkan suatu estimasi tentang seperti apa variabel proses tanpa adanya disturbance dan tundaan waktu ke dalam jalur umpan balik. Hal ini dihasilkan dengan menjalankan keluaran kontroler melalui elemen pertama dari model proses (penguatan dan konstanta waktu), tetapi tidak melalui elemen waktu tunda. Dengan demikian akan memprediksi seperti apa variabel proses disturbance-free setelah adanya tundaan waktu. Prediktor Smith pada dasarnya bekerja untuk mengontrol variabel umpan balik yang dimodifikasi (variabel proses yang diprediksi dengan menyertakan disturbance). Jika tundaan waktu dari prosesnya terlalu lama, maka tidak ada pilihan lain selain menunggu selama waktu tunda tersebut untuk mendeteksi efek dari hadirnya tindakan kontrol pada keluaran proses. Kemudian, sebuah aksi kontrol yang agresif tidak memungkinkan karena tidak ada kesempatan untuk memperbaiki efek samping dari tindakan agresif yang hadir untuk waktu yang lama. Jadi, tundaan waktu adalah salah satu masalah yang paling serius dalam meningkatkan kinerja kontrol. Untungnya, jika model tersedia, maka efek dari tindakan kontrol yang hadir pada keluaran proses ke depannya dapat diprediksi tanpa menunggu sepanjang tundaan waktu. Untuk mengevaluasi kinerja kontrol pada hasil simulasi dianalisis tanggapan transien sistem dalam ranah waktu.

\section{PID Kontroler}

\subsection{Kontroler P (Proportional)}

Pada kontroler jenis $\mathrm{P}$ (proportional) ini terdapat hubungan yang sebanding atau proporsional antara sinyal keluaran terhadap sinyal galat, secara lebih sederhana dapat dikatakan bahwa sinyal keluaran kontroler proporsional merupakan perkalian antara konstanta proporsional dengan sinyal masukannya.Kontroler ini juga lebih dikenal sebagai penguatan. Pertambahan nilai $K_{p}$ akan menaikkan penguatan sistem sehingga dapat digunakan untuk memperbesar kecepatan tanggapan menunjukkan diagram blok yang menggambarkan hubungan antara besaran sinyal referensi, besaran aktual dengan besaran sinyal keluaran kontroler proporsional. Sinyal galat merupakan selisih antara besaran sinyal referensi dengan besaran aktualmya. Selisih ini akan mempengaruhi kontroler, untuk mengeluarkan sinyal positip (mempercepat pencapaian nilai sinyal referensi) atau negatif (memperlambat tercapainya nilai yang diinginkan). $K_{p}$ berlaku sebagai penguat saja tanpa memberikan efek dinamik kepada kinerja kontroler. Penggunaan kontrol $\mathrm{P}$ memiliki berbagai keterbatasan karena sifat kontrol yang tidak dinamik ini. Walaupun demikian dalam aplikasi-aplikasi dasar yang sederhana kontrol $\mathrm{P}$ ini cukup mampu untuk memperbaiki tanggapan transien khususnya rise time dan settling time. Pemakaian alat kontrol tipe proporsional ini sering tidak cukup memuaskan karena penambahan $K_{p}$ selain akan membuat sistem lebih sensitif tetapi juga cenderung mengakibatkan ketidakstabilan. Disamping itu penambahan nilai $K_{p}$ terbatas dan tidak cukup untuk mencapai tanggapan sampai suatu nilai yang diinginkan. Kenyataannya dalam mengatur nilai $K_{p}$ terdapat keadaan-keadaan yang bertentangan. Di satu pihak diinginkan mengurangi error steady state sebanyak mungkin tetapi hal ini akan mengakibatkan osilasi bagi tanggapan yang berarti memperlama "setting time" sedangkan dipihak lain tanggapan terhadap setiap perubahan sinyal masukan harus terjadi secepat mungkin tetapi dengan lonjakan dan osilasi sekecil mungkin. Tanggapan yang cepat memang dapat diperoleh dengan memperbesar $K_{p}$ tetapi hal ini juga akan mengakibatkan ketidakstabilan sistem. Kontroler proporsional memiliki 2 parameter yaitu:

- Pita proporsional (proportional band, $\mathrm{PB}$ )

- $\quad$ Konstanta proporsional $\left(K_{p}\right)$.

Daerah kerja efektif kontroler dicerminkan oleh pita proporsional, sedangkan konstanta proporsional menunjukkan nilai faktor penguatan terhadap sinyal galat, $K_{p}$. Gambar 2 menunjukkan grafik hubungan antara $\mathrm{PB}$, sinyal keluaran kontroler dan sinyal galat yang merupakan sinyal masukan kontroler. Ketika konstanta proporsional bertambah semakin tinggi, pita proporsional menunjukkan penurunan yang semakin kecil, sehingga lingkup kerja yang dikuatkan akan semakin sempit. 


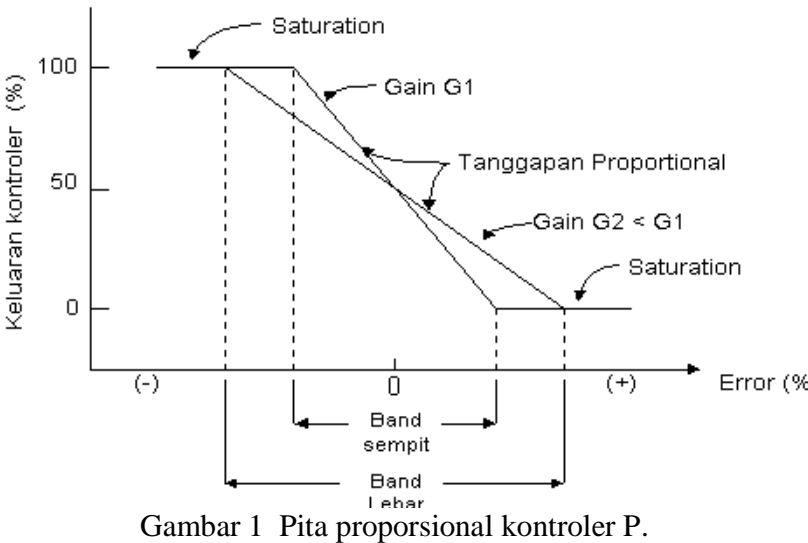

Ketika konstanta proporsional semakin tinggi, pita proporsional menunjukkan penurunan yang semakin kecil, sehingga lingkup kerja yang dikuatkan akan semakin sempit.Ciri-ciri kontroler proporsional harus diperhatikan ketika kontroler tersebut diterapkan pada suatu sistem. Secara eksperimental, pengguna kontroler proporsional harus memperhatikan ketentuan-ketentuan berikut ini:

- Jika nilai $K_{p}$ kecil, kontroler proporsional hanya mampu melakukan koreksi sinyal galat yang kecil, sehingga akan menghasilkan tanggapan sistem yang lambat.

- Jika nilai $K_{p}$ dinaikkan, tanggapan sistem menunjukkan semakin cepat mencapai keadaan tunaknya.

- Jika nilai $K_{p}$ diperbesar sehingga mencapai nilai yang berlebihan, akan mengakibatkan sistem bekerja tidak stabil, atau menyebabkan sistem akan berisolasi.

\subsection{Kontroler I (Integral)}

Pada kontroler ini, kecepatan perubahan sinyal kontrol sebanding dengan sinyal galat. Kontroler jenis I (Integral) bertujuan untuk menghilangkan sinyal galat dalam keadaan tunak tanpa mengubah karakteristikkarakteristik frekuensi tinggi dan hal ini dapat dicapai dengan memberikan penguatan tidak tak terhingga pada frekuensi nol yaitu pada kondisi tunak. Dengan kata lain, kontroler ini berfungsi menghasilkan tanggapan sistem yang memiliki sinyal galat keadaan tunak nol. Kontroler integral berfungsi untuk menghasilkan tanggapan sistem yang memiliki sinyal galat keadaan tunak nol. Jika sebuah plant tidak memiliki unsur integrator $(1 / \mathrm{s})$, kontroler proporsional tidak akan mampu menjamin sinyal keluaran sistem dengan sinyal galat keadaan tunaknya nol. Dengan menggunakan kontroler integral, tanggapan sistem dapat diperbaiki, yaitu mempunyai sinyal galat keadaan tunaknya nol.Kontroler integral memiliki karakteristik seperti halnya sebuah integral. Sinyal keluaran kontroler sangat diperngaruhi oleh perubahan yang sebanding dengan nilai sinyal galat. Sinyal keluaran kontroler ini merupakan jumlahan yang terus menerus dari perubahan masukkannya. Kalau sinyal galat tidak mengalami perubahan, maka sinyal keluaran akan menjaga keadaan seperti sebelum terjadinya perubahan sinyal masukan. Sinyal keluaran kontroler integral merupakan luas bidang yang dibentuk oleh kurva sinyal galat penggerak. sinyal keluaran akan bernilai sama dengan nilai sebelumnya ketika sinyal galat bernilai nol. Sinyal keluaran kontroler integral merupakan luas bidang yang dibentuk oleh kurva sinyal galat penggerak- lihat konsep numerik. Gambar 2 menunjukkan contoh sinyal galat yang disulutkan ke dalam kontroler integral dan sinyal keluaran kontroler integral terhadap perubahan sinyal galat tersebut.

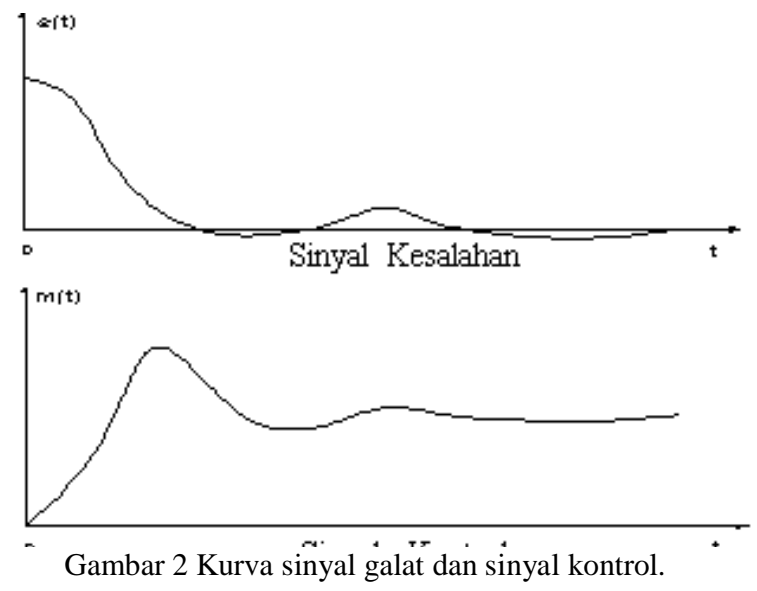

Perhatikan bahwa aksi kontrol integral, disamping menghilangkan ofset atau sinyal galat keadaan tunak, ada kemungkinan menimbulkan tanggapan yang berosilasi dengan amplitudo yang mengecil pelan-pelan atau bahkan amplitudo yang membesar, yang biasanya keduanya tidak diinginkan. Pengaruh perubahan konstanta integral terhadap sinyal keluaran integral ditunjukkan pada Gambar 2. Bila nilai $e(t)$ naik 2 kali, maka laju perubahan $u(t)$ terhadap waktu menjadi 2 kali lebih cepat. Bila $e(t)$ tetap maka nilai $u(t)$ akan tetap seperti semula. Aksi reset setelah ada perubahan beban. Jika nilai konstanta integrator berubah menjadi lebih besar, sinyal galat yang relatif lebih kecil dapat mengakibatkan laju sinyal keluaran menjadi besar. Kontroler integral memiliki karakteristik sebgai berikut: Jika sinyal galat tidak bernilai 0 , maka sinyal keluaran kontroler akan menunjukkan kenaikan atau penurunan yang dipengaruhi oleh besarnya sinyal galat dan nilai $K_{i}$. Jika sinyal galat bernilai nol, maka sinyal keluaran kontroler akan bertahan pada nilai sebelumnya Sinyal keluaran kontroler membutuhkan selang waktu tertentu, sehingga kontroler integral cenderung memperlambat sistem Nilai $K_{i}$ yang bernilai besar dapat mempercepat hilangnya offset. Tetapi semakin besar nilai $K_{i}$ maka aakan mengakibatkan peningkatan osilasi dari sinyal keluaran kontroler. Pengaruh perubahan konstanta integral terhadap sinyal keluaran integral ditunjukkan oleh Gambar 3. 


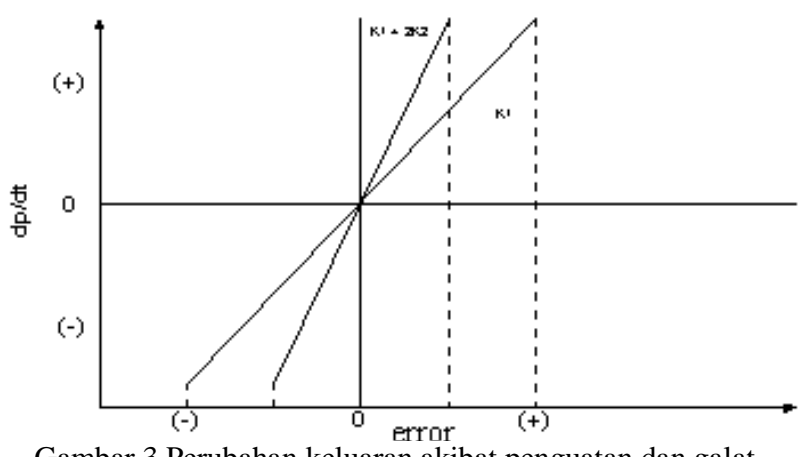

Gambar 3 Perubahan keluaran akibat penguatan dan galat

Ketika sinyal galat berlipat ganda, maka nilai laju perubahan sinyal keluaran kontroler berubah menjadi dua kali dari semula. Jika nilai konstanta integrator berubah menjadi lebih besar, sinyal galat yang relatif kecil dapat mengakibatkan laju sinyal keluaran menjadi besar.

Ketika digunakan, kontroler integral mempunyai beberapa karakteristik berikut ini:

- Sinyal keluaran kontroler membutuhkan selang waktu tertentu, sehingga kontroler integral cenderung memperlambat tanggapan.

- Ketika sinyal galat bernilai nol, sinyal keluaran kontroler akan bertahan pada nilai sebelumnya.

- Jika sinyal galat tidak bernilai nol, sinyal keluaran akan menunjukkan kenaikan atau penurunan yang dipengaruhi oleh besarnya sinyal galat dan nilai $K_{i}$.

- Konstanta integral $K_{i}$ yang bernilai besar akan mempercepat hilangnya offset. Tetapi semakin besar nilai konstanta $K i$ akan mengakibatkan peningkatan osilasi dari sinyal keluaran kontroler.

\subsection{Kontroler D (Derivative)}

Sinyal keluaran kontroler derivatif atau kontroler turunan memiliki sifat seperti halnya suatu operasi derivatif. Perubahan yang mendadak pada sinyal masukan kontroler, akan mengakibatkan perubahan yang sangat besar dan cepat. Aksi kontroler turunan, sering disebut juga kontrol laju (rate control), karena besar sinyal keluaran kontroler sebanding dengan laju perubahan sinyal galat penggerak. Ketika sinyal masukannya tidak mengalami perubahan, sinyal keluaran kontroler juga tidak mengalami perubahan, sedangkan apabila sinyal masukan berubah mendadak dan menaik (berbentuk fungsi step), sinyal keluaran menghasilkan sinyal berbentuk impuls. Jika sinyal masukan berubah naik secara perlahan (fungsi ramp), sinyal keluarannya justru merupakan fungsi step yang besar magnitudnya sangat dipengaruhi oleh kecepatan naik dari fungsi ramp dan konstanta derivatifnya $T_{d}$. Karakteristik kontroler derivatif adalah sebagai berikut:

- Kontroler ini tidak dapat menghasilkan sinyal keluaran bila tidak ada perubahan pada sinyal masukannya (berupa sinyal galat).

- Jika sinyal galat berubah terhadap waktu, maka sinyal keluaran yang dihasilkan kontroler tergantung pada nilai $T d$ dan laju perubahan sinyal galat.
- Kontroler derivatif mempunyai suatu karakter untuk mendahului, sehingga kontroler ini dapat menghasilkan koreksi yang signifikan sebelum pembangkit sinyal galat menjadi sangat besar. Jadi kontroler derivatif dapat mengantisipasi pembangkit sinyal galat, memberikan aksi yang bersifat korektif, dan cenderung meningkatkan stabilitas sistem.

Gambar 4 menunjukkan kurva waktu hubungan antara sinyal masukan dan sinyal keluaran kontroler derivatif.

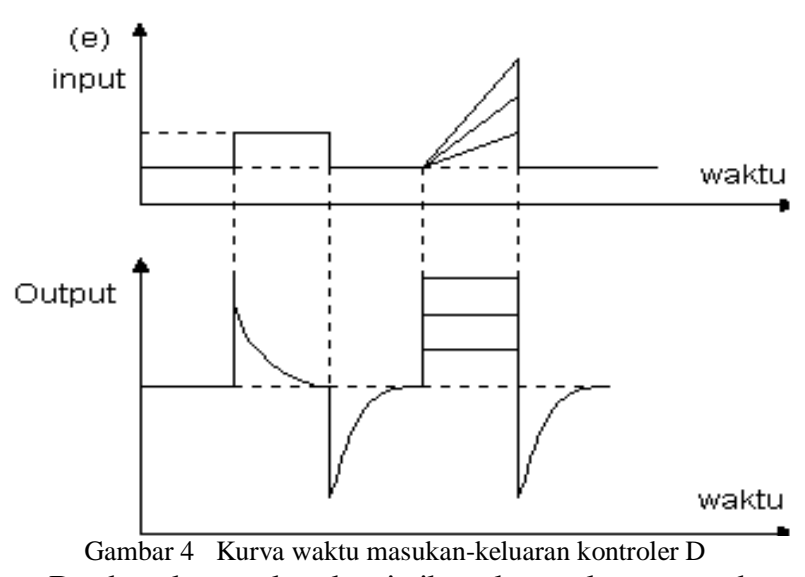

Berdasarkan karakteristik kontroler tersebut, kontroler derivatif umumnya dipakai untuk mempercepat tanggapan awal suatu sistem, tetapi tidak memperkecil sinyal galat pada keadaan tunaknya. Kerja kontrolller derivatif hanyalah efektif pada lingkup yang sempit, yaitu pada periode peralihan. Oleh sebab itu kontroler derivatif tidak pernah digunakan tanpa ada kontroler lain sebuah sistem. Disamping mempunyai keunggulan dalam mendahului, aksi kontrol turunan mempunyai kelemahan dalam hal memperkuat sinyal derau sehingga dapat menimbulkan pengaruh saturasi pada aktuator. Aksi kontrol turunan cenderung menghilangkan atau memperkecil sinyal galat keadaan tunak dari tanggapan terhadap berbagai sinyal masukan. Walaupun kontrol turunan tidak mempengaruhi sinyal galat keadaan tunak secara langsung, akan tetapi menambah redaman sistem sehingga memungkinkan penggunaan nilai penguatan yang lebih besar sehingga akan memperbaiki ketelitian keadaan tunak. Karena kontrol turunan bekerja berdasarkan laju perubahan sinyal galat penggerak, bukan berdasarkan pada sinyal galat penggerak itu sendiri, serta kerja kontroler derivatif hanyalah efektif pada lingkup yang sempit, yaitu hanya efektif pada periode peralihan atau periode transien. Dengan sifat ini ia dapat digunakan untuk memperbaiki tanggapan transien dengan memprediksi sinyal galat yang akan terjadi. Kontrol Derivatif hanya berubah saat ada perubahan sinyal galat sehingga saat sinyal galat statis atau tetap kontrol ini tidak akan bereaksi, hal ini pula yang menyebabkan kontroler Derivatif tidak dapat dipakai sendiri.

\subsection{Kontroler PID}

Kontoller PID merupakan kontroler berumpan balik yang terdiri dari 3 jenis pengaturan yang saling 
dikombinasikan, yaitu Kontroler P, Kontroler D, dan Kontroler I yang masing-masing secara keseluruhan bertujuan untuk mempercepat reaksi sebuah sistem, menghilangkan offset, dan menghasilkan perubahan awal yang besar. Sistem Kontrol PID merupakan kontroler untuk menentukan presisi suatu sistem instrumentasi dengan karakteristik adanya umpan balik pada sistem.Sistem kontrol PID terdiri dari tiga buah cara pengaturan yaitu kontrol P (Proportional), D (Derivative) dan I (Integral), dengan masing-masing memiliki kelebihan dan kekurangan. Dalam implementasinya masing-masing cara dapat bekerja sendiri maupun gabungan diantaranya. Dalam perancangan sistem kontrol PID yang perlu dilakukan adalah mengatur parameter P, I atau D agar tanggapan sinyal keluaran sistem terhadap sinyal masukan tertentu sebagaimana yang diinginkan

Untuk mendapatkan aksi kontrol yang baik diperlukan langkah-langkah sebagai berikut:

- Memahami cara kerja sistem,

- Mencari model sistem dinamik dalam persamaan differensial,

- Mendapatkan fungsi alih sistem dengan Transformasi Laplace,

- Memberikan aksi pengontrolan dengan menentukan konstanta-konstanta kontroler yang sesuai,

- Menggabungkan fungsi alih yang sudah didapatkan dengan jenis aksi pengontrolan,

- Menguji sistem dengan sinyal masukan fungsi langkah, fungsi undak dan impuls ke dalam fungsi alih yang baru,

- Melakukan Transformasi Laplace balik untuk mendapatkan fungsi dalam kawasan waktu,

- Menggambar tanggapan sistem dalam kawasan waktu

Setiap kekurangan dan kelebihan dari masing-masing kontroler P, I, D dapat saling menutupi dengan menggabungkan ketiganya secara paralel. Kontroler PID merupakan jumlahan dari sinyal keluaran kontroler proporsional, sinyal keluaran kontroler integral dan sinyal keluaran kontroler derivatif. Karakteristik kontroler PID sangat dipengaruhi oleh kontribusi besar ketiga parameter dari P, I dan D. Penalaan konstanta $K_{p}$, $T_{i}$, dan $T_{d}$ akan mengakibatkan penonjolan sifat dari masing-masing elemen. Satu atau dua dari ketiga konstanta tersebut dapat disetel lebih menonjol dibanding yang lain. Konstanta yang menonjol itulah akan memberikan kontribusi pengaruh pada tanggapan sistem secara keseluruhan. Parameter-parameter tersebut tidak bersifat independen, sehingga pada saat salah satu nilai konstantanya diubah, maka mungkin sistem tidak akan bereaksi seperti yang diinginkan. Rangkaian kontroler PID:

- Kontroler proporsional $K_{p}$ akan memberikan efek mengurangi waktu naik tetapi tidak menghapus sinyal galat keadaan tunak.

- Kontroler integral $K_{i}$ akan memberikan efek menghapus sinyal galat keadaan tunak tetapi berakibat memburuknya tanggapan transient.
- Kontroler derivatif $K_{d}$ akan memberikan efek meningkatnya stabilitas sistem, mengurangi lewatan maksimum dan menaikkan tanggapan fungsi trasnfer.

Salah satu permasalahan terbesar dalam desain kontroler PID yaitu masalah tuning untuk menentukan nilai $K_{i}, K_{p}$, dan $K_{d}$ yang pas. Metode-metode tuning dilakukan berdasarkan model matemetika plant/sistem. Jika model tidak diketahui, maka dilakukan eksperimen terhadap sistem. Bisa juga menggunakan cara trial and error. Kontroler PID ini merupakan jenis kontroler yang paling populer digunakan yang banyak diterapkan didunia industri. Luasnya penggunaaan kontroler PID pada dasarnya dilatar belakangi oleh beberapa hal diantaranya kesederhanaan struktur kontrol. Selain hanya ada 3 parameter utama yang perlu diatur, pengaruh perubahan setiap parameter PID terhadap dinamika pengontrolan secara intuitif mudah dipahami oleh operator. Elemen-elemen kontroler P, I dan D masing-masing secara keseluruhan bertujuan untuk mempercepat reaksi sebuah sistem, menghilangkan offset dan menghasilkan perubahan awal yang besar. Gambar 5 menunjukkan diagram blok kontroler PID.

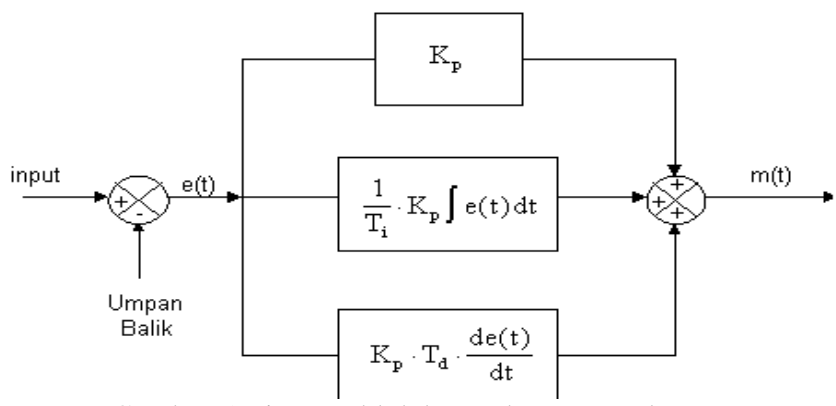

Gambar 5 Diagram blok kontroler PID analog

Sinyal keluaran kontroler PID merupakan jumlahan dari sinyal keluaran kontroler proporsional, sinyal keluaran kontroler integral. Gambar 6 menunjukkan hubungan tersebut.
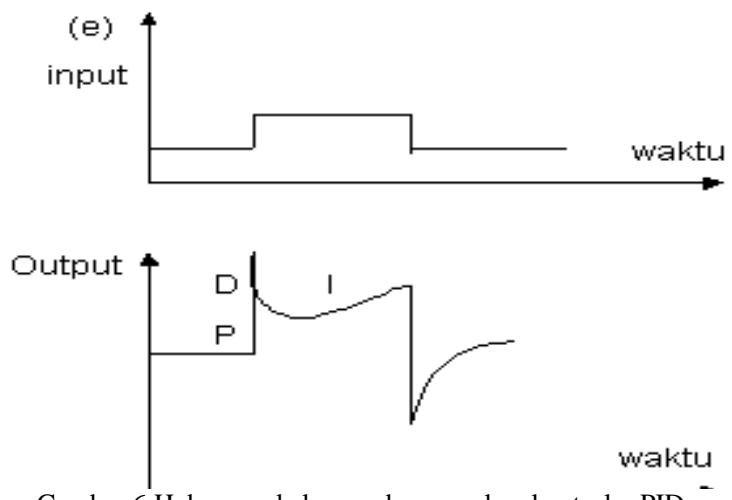

Gambar 6 Hubungan keluaran dan masukan kontroler PID -

Karakteristik kontroler PID sangat dipengaruhi oleh kontribusi besar dari ketiga parameter P, I dan D. Penalaan konstanta $K_{p}, T_{i}$, dan $T_{d}$ akan mengakibatkan penonjolan sifat dari masing- masing elemen. Satu atau dua dari ketiga konstanta tersebut dapat disetel lebih menonjol dibanding yang lain. Konstanta yang menonjol 
itulah akan memberikan kontribusi pengaruh pada tanggapan sistem secara keseluruhan.

\section{Simulasi dan Analisis Prediktor Smith}

Strategi Smith terdiri dari sebuah loop umpan balik biasa ditambah loop dalam yang memperkenalkan dua istilah tambahan yang secara langsung ke jalur umpan balik. Istilah pertama adalah estimasi terhadap seperti apa variabel proses tanpa adanya disturbance apapun. Hal ini dihasilkan dengan menjalankan keluaran kontroler melalui model proses yang sengaja mengabaikan efek dari disturbance beban. Jika model ini tidak akurat dalam mewakili perilaku proses, keluarannya akan menjadi versi disturbance-free dari variabel proses yang sebenarnya.Model matematika yang digunakan untuk menghasilkan variabel proses disturbance-free memiliki dua elemen yang dihubungkan secara seri. Pertama mewakili semua perilaku proses yang tidak disebabkan oleh time-delay. kedua hanya time-delay. Unsur bebas-time-delay umumnya diimplementasikan sebagai derivatif biasa atau persamaan difference yang mencakup estimasi dari semua gain proses dan konstanta waktu proses. Elemen kedua adalah penundaan waktu. Sinyal yang masuk ke dalamnya menjadi tertunda saat keluar, sedangkan jika pada kondisi sebaliknya tidak berubah. Strategi Smith menghadirkan suatu estimasi tentang seperti apa variabel proses tanpa adanya disturbance dan time-delay ke dalam jalur umpan balik. Hal ini dihasilkan dengan menjalankan keluaran kontroler melalui elemen pertama dari model proses (penguatan dan konstanta waktu), tetapi tidak melalui elemen waktu tunda. Ini dengan demikian akan memprediksi seperti apa variabel proses disturbance-free setelah time-delay telah. Mengurangkan variabel proses disturbance-free dari variabel proses yang sebenarnya menghasilkan suatu estimasi disturbance. Dengan menambahkan perbedaan ini ke variabel proses yang diprediksi, Smith menciptakan sebuah variabel umpan balik yang mencakup disturbance, tetapi bukan time-delay tersebut. Hal ini juga menunjukkan estimasi variabel proses (dengan disertai disturbance dan time-delay) yang dihasilkan dengan menambahkan disturbance yang sudah terestimasi kembali menjadi variabel proses yang tanpa disturbance (disturbance-free process). Hasilnya adalah sistem kontrol umpan balik dengan time-delay di luar loop.Prediktor smith pada dasarnya bekerja untuk mengontrol variabel umpan balik yang dimodifikasi (variabel proses yang diprediksi dengan menyertakan disturbance). Jika berhasil dalam melakukannya, dan jika tanggapan model proses persis sama dengan tanggapan proses, maka kontroler secara bersamaan akan mendorong variabel proses yang sebenarnya ke arah setpoint apakah setpoint berubah atau beban mengganggu proses. Lebih mudah bagi kontroler untuk memenuhi tujuannya tanpa berurusan dengan timedelay, tapi bukan suatu hal yang selalu mudah untuk menghasilkan model proses yang diperlukan untuk mencapai strategi tersebut. Ada beberapa perbaikan yang diusulkan untuk memperbaiki Prediktor smith dasar, tapi time- delay tetap menjadi masalah kontrol sangat sulit. Bahkan sedikit saja ketidakcocokan antara proses dan model dapat menyebabkan kontroler akan menghasilkan keluaran yang berhasil memanipulasi variabel umpan balik yang dimodifikasi, tapi menggerakkan variabel proses yang sebenarnya menjadi terlupakan. Jika time-delay dari prosesnya terlalu lama, maka tidak ada pilihan lain selain menunggu selama waktu tunda tersebut untuk mendeteksi efek dari hadirnya tindakan kontrol pada keluaran proses. Kemudian, sebuah aksi kontrol yang agresif tidak memungkinkan karena tidak ada kesempatan untuk memperbaiki efek samping dari tindakan agresif yang hadir untuk waktu yang lama. Jadi, time-delay adalah salah satu masalah yang paling serius dalam meningkatkan kinerja kontrol. Untungnya, jika model tersedia, maka efek dari tindakan kontrol yang hadir pada keluaran proses ke depannya dapat diprediksi tanpa menunggu sepanjang time-delay dengan cara memecahkan persamaan diferensial model menggunakan komputer. Pada penelitian ini dihadirkan analisis dan simulasi dari pendekatan prediktor Smith untuk mengkompensasi time-delay.

Jika kita perhatikan sistem kontrol sebagaimana diperlihatkan pada Gambar 6, dimana $G^{*}(s)$ merupakan proses time-delay-free dan $G_{m}^{*}(s)$ merupakan model time-delay-free. $G(s)=\exp (-\theta s) G^{*}(s) \quad$ adalah proses. $G_{c}(s)$ biasanya adalah kontroler PID. Keluaran model $y_{m}^{*}(s)$ merupakan keluaran proses time-delay-free hasil simulasi. $y_{m}^{*}(s)$ berkorespondensi dengan $y^{*}(s)=G^{*}(s) u(s)$. Jika model $G_{m}^{*}(s)=G^{*}(s)$, maka ini merupakan ekivalen dari kendali proses timedelay-free, sebagaimana diperlihatkan pada Gambar 7.

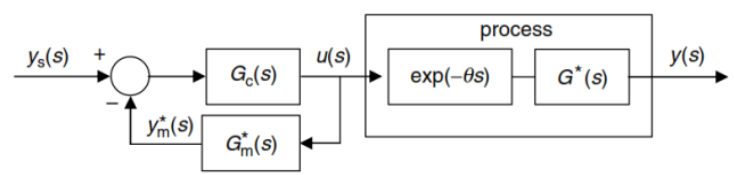

Gambar 6 Kontrol prediktif menggunakan model proses

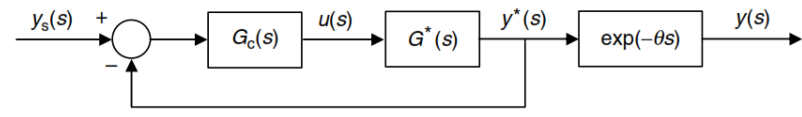

Gambar 7 Sistem kontrol equivalen dari Gambar 16

Dalam hal ini, keluaran proses merupakan keluaran time-delay-free yang tertunda; yaitu,

$$
y(t)=y^{*}(t-\theta)
$$

Ingat bahwa kontroler $G_{c}(s)$ menggunakan sinyal $y^{*}(s)$. Sehingga, dengan begini memungkinkan untuk mendeteksi efek-efek dari aksi kontrol saat ini pada keluaran proses tanpa menunggu selama waktu tunda. Jadi, kontroler dapat ditala secara tepat karena tidak ada 
waktu tunda di dalam loop umpan balik, yang menghasilkan tanggapan loop tertutup yag cepat.

Secara praktis, karena selalu ada galat pemodelan, loop umpan balik untuk mengkompensasi galat pemodelan seharusnya dimasukkan, sebagaimana diperlihatkan pada Gambar 8. Loop umpan balik mengurangi nilai referensi (setpoint) sebesar nilai galat pemodelan, yang dihasilkan dalam kondisi tanpa offset.

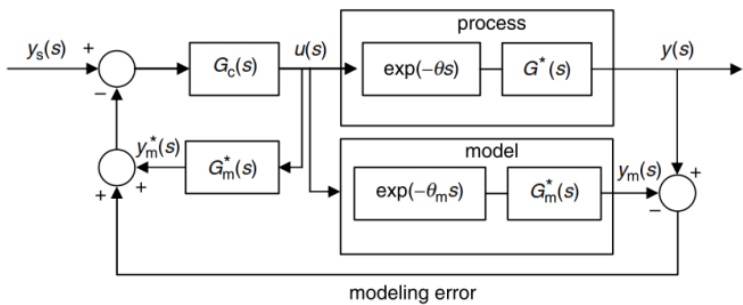

Gambar 8 Prediktor Smith

Dari Gambar 8 dapat diperoleh persamaan karakteristik prediktor Smith sebagai berikut

$$
\begin{gathered}
1+G_{c}(s) G_{m}^{*}(s)+G_{c}(s)\left(G_{p}(s)-G_{m}(s)\right)=0 \\
1+G_{c}(s)\left(G_{m}^{*}(s)+G_{p}(s)-G_{m}(s)\right)=0
\end{gathered}
$$

dimana

$$
G(s)=\exp (-\theta s) G^{*}(s)
$$

adalah proses dan

$$
G_{m}(s)=\exp \left(-\theta_{m} s\right) G_{m}^{*}(s)
$$

adalah model.

Jika diasumsikan bahwa tidak ada galat pemodelan (yaitu, $G_{p}(s)-G_{m}(s)=0$ ), maka kontroler $G_{c}(s)$ harus ditala pada basis dari model time-delay-free $G_{m}^{*}(s)$. Ingat bahwa $G_{m}^{*}(s)$ tidak mempunyai tundaan waktu. Sehingga, penguatan (gain) kontroler yang diberikan ke $G_{c}(s)$ bisa sampai pada nilai tak terbatas dengan aturanaturan penalaan PID biasa. Artinya bahwa, Penguatan yang tak terbatas tidak diharapkan, karena penguatan yang sangat besar akan menyebabkan ketidak stabilan sistem loop tertutup melalui penguatan galat pemodelan.Prediktor Smith menunjukkan kinerja yang baik dalam penjejakan setpoint karena $G_{c}(s)$ ditala dengan tegas dan menggunakan keluaran model timedelay-free.

$$
1+G_{c}(s) G_{m}^{*}(s)=0
$$

jika tidak terdapat galat pemodelan. Sehingga, jelas bahwa $G_{c}(s)$ dapat ditala dengan tegas karena $G_{m}^{*}(s)$ tidak mempunyai tundaan waktu. Tetapi, harus dicatat bahwa galat pemodelan $G_{p}(s)-G_{m}(s)$ diperkuat oleh gain kontroler yang bernilai tinggi dari $G_{c}(s)$. Sebagai dampaknya, kestabilan loop tertutup cenderung menjadi sangat sensitif terhadap galat pemodelan $G_{p}(s)-G_{m}(s)$. Sehingga, dengan galat pemodelan yang kecil saja, dapat menyebabkan sistem loop tertutup menjadi tidak stabil. Prediktor Smith mampu menghadirkan kinerja penjejakan setpoint yang 'excellent' jika model proses akurat. Tetapi, galat model yang bernilai kecil dapat menyebabkan ketidak stabilam sistem loop tertutup jika nilai penguatan kontroler ditala terlalu tegas. Prediktor Smith dapat ditala dengan cara yang baik dengan memperhatikan nilai galat pemodelan dalam bentuk penguatan ekivalen disertai tundaan waktu.Untuk mengamati perbandingan antara kinerja kontroler PID konvensional dan kinerja prediktor Smith dalam penelitian ini, diambil contoh kasus sebagai berikut:

- Persamaan proses: $G(s)=\frac{\exp (-1,8 s)}{s^{2}+2 s+1}$

- Persamaan model: $G_{m}(s)=0,95 \frac{\exp (-1,7 s)}{s^{2}+2,2 s+1}$

Diasumsikan galat pemodelan sebesar $7 \%$ untuk penguatan dan tundaan waktu yang ekivalen, yaitu:

$$
G_{m}^{*}(s)+G_{p}(s)-G_{m}(s) \approx G_{m}^{*}(s) 1,07 \exp (-1,7 \times 0,07 s)
$$

Hasil simulasi komputer perbandingan antara kinerja kontroler PID konvensional dan kinerja prediktor Smith diperlihatkan pada Gambar 9.

Solusinya adalah

$$
G_{m}^{*}(s) 1,07 \exp (-1,7 \times 0,07 s)=0,95 \frac{\exp (-1,7 s)}{s^{2}+2,2 s+1}
$$

harus digunakan untuk menala kontroler PID prediktor Smith.

Berdasarkan ITAE-2 tuning rule:

$$
\begin{aligned}
& G_{c}(s)=8,455\left(1+\frac{1}{2,270 s}+0,456 s\right), \\
& G_{m}(s)=0,95 \times 1,07 \frac{\exp (-1,7 \times 0,07 s)}{s^{2}+2,2 s+1}
\end{aligned}
$$

dan

$$
G_{m}^{*}(s)=0,95 \times 1,07 \frac{\exp (-0,0 s)}{s^{2}+2,2 s+1}
$$

harus digunakan untuk model prediktor Smith.

Kontroler PID konvensional yang dirancang berbasis model berdasarkan ITAE-2 tuning rule

$$
G_{m}(s)=0,95 \frac{\exp (-1,7 s)}{s^{2}+2,2 s+1}
$$

adalah

$$
G_{c}(s)=1,027\left(1+\frac{1}{2,560 s}+0,751 s\right) .
$$

Hasil simulasi komputer menggunakan program Matlab mengenai kinerja kontrol prediktor Smith dan kontoler PID konvensional diperlihatkan pada Gambar 9.

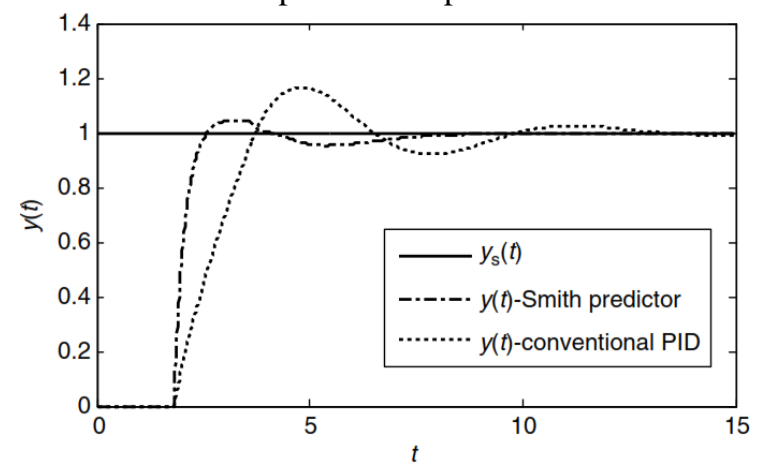




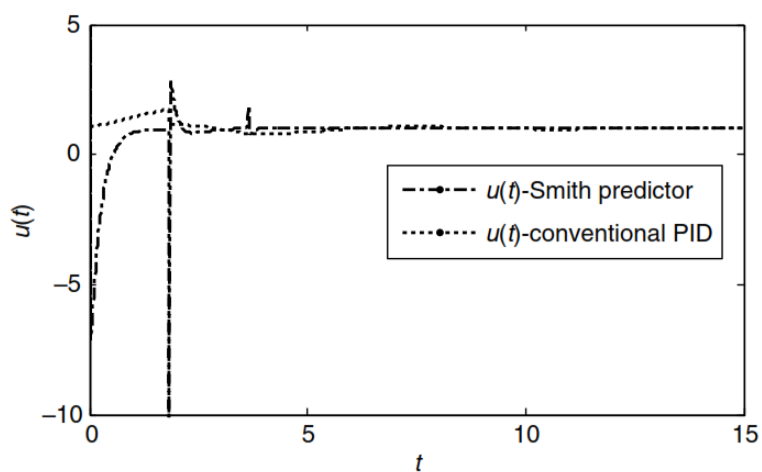

Gambar 9 Kinerja kontrol prediktor Smith dan kontoler PID konvensional

Tanggapan loop tertutup sangat cepat karena parameter-parameter kontroler PID prediktor Smith dapat ditala secara tegas, sementara kontroler PID konvensional menunjukkan tanggapan loop tertutup yang lebih lambat.

\section{Kesimpulan}

Strategi prediktor Smith digunakan untuk mengkompensasi time-delay di dalam suatu sistem dinamis sehingga dapat memperbaiki kinerja kontroler PID konvensional. Jika time-delay dari prosesnya terlalu lama, maka tidak ada pilihan lain selain menunggu selama waktu tunda tersebut untuk mendeteksi efek dari hadirnya tindakan kontrol pada keluaran proses. Kemudian, sebuah aksi kontrol yang agresif tidak memungkinkan karena tidak ada kesempatan untuk memperbaiki efek samping dari tindakan agresif yang hadir untuk waktu yang lama. Jadi, time-delay adalah salah satu masalah yang paling serius dalam meningkatkan kinerja kontrol. Untungnya, jika model tersedia, maka efek dari tindakan kontrol yang hadir pada keluaran proses ke depannya dapat diprediksi tanpa menunggu sepanjang time-delay. Model matematika yang digunakan untuk menghasilkan variabel proses disturbance-free memiliki dua elemen yang dihubungkan secara seri. Pertama, mewakili semua perilaku proses yang tidak disebabkan oleh time-delay. Kedua, hanya time-delay.

Unsur time-delay-free umumnya diimplementasikan sebagai turunan biasa atau persamaan difference yang mencakup estimasi dari semua penguatan (gain) proses dan konstanta waktu proses. Sinyal yang masuk ke dalamnya menjadi tertunda saat keluar, sedangkan jika pada kondisi sebaliknya tidak berubah. Strategi Smith menghadirkan suatu estimasi tentang seperti apa variabel proses tanpa adanya disturbance dan time-delay ke dalam jalur umpan balik. Hal ini dihasilkan dengan menjalankan keluaran kontroler melalui elemen pertama dari model proses (penguatan dan konstanta waktu), tetapi tidak melalui elemen waktu tunda. Dengandemikian akan memprediksi seperti apa variabel proses disturbance-free setelah adanya time-delay. Prediktor smith pada dasarnya bekerja untuk mengontrol variabel umpan balik yang dimodifikasi (variabel proses yang diprediksi dengan menyertakan disturbance).
Prediktor Smith mampu menghadirkan kinerja penjejakan setpoint yang 'excellent' jika model proses akurat. Tetapi, galat model yang bernilai kecil dapat menyebabkan ketidak stabilan sistem loop tertutup jika nilai penguatan kontroler ditala terlalu tegas. Prediktor Smith dapat ditala dengan cara yang baik dengan memperhatikan nilai galat pemodelan dalam bentuk penguatan ekivalen disertai tundaan waktu. Tanggapan loop tertutup sangat cepat karena parameter-parameter kontroler PID prediktor Smith dapat ditala secara tegas, sementara kontroler PID konvensional menunjukkan tanggapan loop tertutup yang lebih lambat.

\section{Referensi}

[1] Feyzmahdavian, H., R., Performance Analysis of Positive Systems and Optimization Algoriths with Time-Delays, Doctoral Thesis, Stockholm, Sweden, 2016.

[2] Gerald Matz, Franz Hlawatsch, Fundamentals of timevarying communication channels, The Netherlands Academic Press, 2011.

[3] Johnson, Curtis: Process Control Instrumentation Technology, Englewood Cliffs, New Jersey, 1988

[4] Malek, M., et. al., Time delay system, Elsevier Science Publisher, 1987.

[5] Ogata, Katsuhiko: Teknik Kontrol Automatik terjemahan: Ir. Edi Laksono, Erlangga, Jakarta, 1991

[6] Su Whan Sung, et. al., Enhanced Control Strategy, IEEE Press, IEEE Communication Sosiety, John Wiley \& Sons Pte Ltd, pp. 215-232, 2009.

[7] Ziegler, J. G. dan N.B. Nichols, Optimum Setting for Automatic Kontrolers, Tans. ASME, vol. 64, pp. 759-768, 1942. 